\title{
Ankara Üniversitesi Ziraat Fakültesi Haymana Araștırma ve Uygulama Çiftliği Topraklarının Verimlilik Durumlarını İncelenmesi
}

\author{
Mahmut Reșat SOBA ${ }^{1^{*}} \quad$ Ferhat TÜRKMEN ${ }^{2} \quad$ Mehmet Burak TAȘKIN ${ }^{3}$ \\ M. Onur AKÇA ${ }^{3} \quad$ H. Sabri ÖZTÜRK ${ }^{3}$ \\ 'Toprak, Gübre ve Su Kaynakları Merkez Araștırma Enstitüsü, Ankara \\ ${ }^{2}$ Ordu Üniversitesi, Ziraat Fakültesi, Toprak Bilimi ve Bitki Besleme Bölümü, Ordu \\ ${ }^{3}$ Ankara Üniversitesi, Ziraat Fakültesi, Toprak Bilimi ve Bitki Besleme Bölümü, Ankara
}

*Sorumlu yazar e-posta (Corresponding author e-mail): mresatsoba@gmail.com

Geliș tarihi (Received) : 01.12.2014

Kabul tarihi (Accepted) : 03.03.2015

\section{Öz}

Ankara Üniversitesi Ziraat Fakültesi Haymana Araștırma ve Uygulama Çiftliği'nde detaylı bir toprak çalıșması hassas tarım uygulamaları ve doğru bir üretim planlaması için gerekli hale gelmiștir. Çiftlik topraklarının verimlilik durumlarının incelenmesi amacıyla 65 adet toprak örneği alınmıștır. Alınan toprak örneklerinin fiziksel, kimyasal özellikleri ile besin maddesi içerikleri belirlenmiștir. Analiz sonuçlarına göre; toprakların büyük bir kısmı ağır bünyeli, hafif alkali, tuzsuz, kireçli ve organik maddece yetersiz bulunmuștur. Toprakların toplam azot (N), alınabilir potasyum (K), çinko (Zn) ve bakır (Cu) içerikleri yeterli bulunmușken, alınabilir fosfor (P) (toprakların \%58, 9 1'i), alınabilir demir (Fe) (toprakların tamamı), alınabilir mangan (Mn) (toprakların tamamı) ve alınabilir çözünebilir bor (B) (toprakların \% 95, 91 'i) içerikleri yetersiz bulunmuștur. Yapılan korelasyon analizi sonucunda kil-silt, kil-kum, kum-Fe, kireç-Zn, kireç-Cu arasında negatif ilișki saptanmıșken, kil- Fe, silt- kum, OM- EC, OM- B, OM- Fe, OM- Zn, pH- EC, EC- K, EC- B, EC$\mathrm{Fe}, \mathrm{EC}-\mathrm{Zn}, \mathrm{EC}-\mathrm{Cu}, \mathrm{EC}-\mathrm{Mn}, \mathrm{P}-\mathrm{K}, \mathrm{P}-\mathrm{Zn}, \mathrm{P}-\mathrm{Cu}, \mathrm{K}-\mathrm{B}, \mathrm{K}-\mathrm{Zn}, \mathrm{K}-\mathrm{Cu}, \mathrm{K}-\mathrm{Mn}, \mathrm{B}-\mathrm{Fe}, \mathrm{B}-\mathrm{Zn}, \mathrm{B}-\mathrm{Cu}, \mathrm{B}-\mathrm{Mn}, \mathrm{Fe}-\mathrm{Zn}$, Fe- Cu, Fe- Mn, Zn- Cu, Zn- Mn arasında pozitif ilișki belirlenmiștir.

Anahtar Kelimeler: Besin elementleri, toprak verimliliği

\section{Investigation of Soil Fertility of Ankara University Faculty of Agriculture Haymana Research and Application Farm}

\begin{abstract}
A detailed soil survey has become necessary for precision farming practices and accurate production planning in Haymana Research and Application Farm of Faculty of Agriculture in Ankara University. Sixty five soil samples were collected to investigate the fertility of farm soil. Physical, chemical properties and nutrient content of the soil samples were analysed. According to these analysis; the majority of soils were found heavy structured, slightly alkaline, saltless, limy and they contain insufficient amount of organic substance. Total nitrogen (N), extractable potassium $(\mathrm{K})$, zinc $(\mathrm{Zn})$ and copper $(\mathrm{Cu})$ contents are found sufficient while their extractable phosphorus (P) (58.91\% of the soil), extractable iron (Fe) (All of the soil), extractable manganese (Mn) (All of the soil) and water-soluble boron (B) (95.91\% of the soil) content are found inadequate. Based on the results of correlation analysis, it is determined that there is a negative correlation between clay-silt, clay-sand, sand-Fe, lime-Zn-Cu while there is a positive correlation between lime-Fe, sand, OM- EC, OM- B, OM- Fe, OM- Zn, pH- EC, EC- K, EC- B, EC- Fe, EC- Zn, EC-Cu, EC- Mn, P- K, P- Zn, P-Cu, K-B, K- Zn, K- Cu, K- Mn, B- Fe, B- Zn, B- Cu, B- Mn, Fe- Zn, Fe- Cu, Fe- Mn, Zn- Cu, Zn- Mn..
\end{abstract}

Key Words: Nutrient elements, soil fertility 


\section{Gíriș}

Toprak verimliliğinin sürdürülebilirliği, toprağın doğal verimliliğinin korunarak kimyasal girdilerin en az düzeyde tutulması ve çevresel etki değerlendirmesini esas almaktadır (Karaman vd., 2012). Sanayileșme ve çarpık kentleșme sonucu hızla kirlenen ve kullanılabilir alanları gittikçe daralan tarım topraklarımızın sürdürülebilirliği ve toprakların optimum kullanılması, toprakların fiziksel ve kimyasal özelliklerinin iyi bir șekilde bilinmesini ve bu özelliklere göre amenajman tedbirlerinin alınmasını zorunlu kılmaktadır. Bitkilerin gelișebilmeleri için gereksinim duydukları besin maddelerinin yetiștirme ortamında uygun oran ve miktarda bulunması gerekmektedir. Besin maddelerinden birinin ya da birkaçının eksikliği veya fazlalığı bitki gelișimini ve bitkilerin toprakta bulunan besin maddelerinden yeterince yararlanmalarını sınırlandırmakta ve sonuçta bol ve kaliteli ürün alınması olumsuz yönde etkilenmektedir. Besin maddelerinin topraktan bitkiler tarafından sürekli olarak sömürülmesi, bilinçsiz gübre kullanılması ve erozyon sonucu tarım yapılan topraklar günden güne verimsizleșmektedir. Çeșitli yollarla topraktan eksilen bitki besin elementlerinin toprağa geri kazandırılması zorunludur. Topraktan eksilen veya toprakta bitki gelișimi için yeterli düzeyde bulunmayan bitki besin elementleri ancak toprak analizleri sonucu belirlenebilmektedir. Ülkemizde bitki çeșidine göre veya bölgesel anlamda toprak analizlerinin önemi son yıllarda anlașılmıș ve bu konuya ağırlık verilmeye bașlanmıștır (Taban vd., 2004).

Orta Anadolu'da çeltik tarımı yapılan alanların verimlilik durumlarını ortaya koymak için yapılan çalıșmada alınan toprakların \%60'ında toplam N, \%25'inde alınabilir $\mathrm{P}, \% 30$ 'unda alınabilir $\mathrm{Zn}$ ve \%90'ında da alınabilir Mn noksanlığı belirlemișlerdir. Toprakların tuzluluk açısından sorun olmadığı ve toprakların \%45'inde organik maddenin yetersiz olduğunu bildirmișlerdir (Taban ve vd., 1997).

Türkiye topraklarının verimlilik durumunu belirlemek amacıyla yapılmıș olan çalıșmada; toprakların büyük bir kısmının tınlı ve killi tınlı, hafif alkali, tuzsuz ve kireçli, organik maddesinin ve alınabilir $\mathrm{P}$ miktarı az, alınabilir $\mathrm{K}$ miktarının ise yüksek olduğu bildirilmiștir (Eyüpoğlu, 1999).

Eldivan yöresinde yetiștirilen kirazların makro ve mikro besin elementleri bakımından beslenme durumunun belirlenmesi amacıyla alınmıs toprak örneklerinin nötr ve hafif alkali pH'ya, sırasıyla kumlu killi tın, killi tın ve kil bünyeye, orta derecede kireç ve düșük organik maddeye sahip olduğu belirlenmiștir. Toplam N, alınabilir K, Fe ve Mn yetersiz bulunmușken, yüksek düzeyde alınabilir Mg ve yeterli düzeyde alınabilir Cu ve Zn olduğunu bildirmișlerdir (Bașaran ve Okant, 2005).

Eceabat ilçesi tarım topraklarının verimlilik durumlarını belirlemek amacıyla yapılan çalıșmada; toprakların hafif alkalin, tuzsuz, düșük organik madde, yüksek alınabilir potasyum ve değișik miktarlarda kireç içerdiği belirlenmiștir. Toprakların alınabilir $\mathrm{P}, \mathrm{Zn}$ ve Mn miktarları yetersiz, alınabilir Ca, Mg ve Cu miktarları ise yeterli düzeyde olduğunu bildirmișlerdir (Parlak vd., 2008).

Bursa ili alüviyal büyük toprak grubu tarım topraklarının verimlilik durumlarının ortaya konması ve potansiyel beslenme sorunlarını saptamak amacıyla alınmıș toprak örneklerinin genel olarak orta bünyeli, hafif alkali reaksiyonlu olduğu, az ve orta düzeyde kireç içeren toprakların \%43,39'unun organik madde, \%46,66'sının toplam N, \%10'unun alınabilir $P, \% 43,34$ 'ünün alınabilir $Z n$ ve \%90'ının alınabilir $M n$ bakımından yetersiz olduğu belirlenmiștir. Toprakların \%23.33'ünde alınabilir K, $\% 43,33$ 'ünde alınabilir Ca, \%73,33'ünde alınabilir Mg, \%50'sinde alınabilir P, \%90'ında alınabilir Fe ve tamamında alınabilir Cu miktarının yeterli olduğunu bildirmișlerdir (Turan vd., 2010).

Ankara Üniversitesi Ziraat Fakültesi Haymana Araștırma ve Uygulama Çiftliği'nde birçok çalıșma yürütülmüș olup, bu șekilde detaylı bir çalıșma yapılmamıștır. Bu araștırma ile çiftlik topraklarının verimlilik durumlarının belirlenerek bundan sonra yapılacak çalıșmalara katkı sağlanması amaçlanmıștır.

\section{MATERYAL ve METOT}

\section{Araștırma Alanının Coğrafik Durumu}

Araștırmanın yürütüldüğü Haymana ilçesi Ankara'nın güneyinde bulunmakta (Șekil 1) ve ilçenin doğusunda Bala ve Gölbașı, güneyinde Kulu ve Cihanbeyli, batısında Polatlı ve kuzeyinde Gölbașı ve Yenimahalle ilçeleri yer almaktadır. Yüzölçümü 2983 km² olan ilçenin, denizden yüksekliği ortalama 1259 metredir (Anonim 2011a, 2015a, 2015b). Haymana Araștırma ve Uygulama Çiftliği 472686475754 doğu boylamları, 4386233- 4383600 kuzey enlemleri arasında yer almaktadır (Șekil 2). 

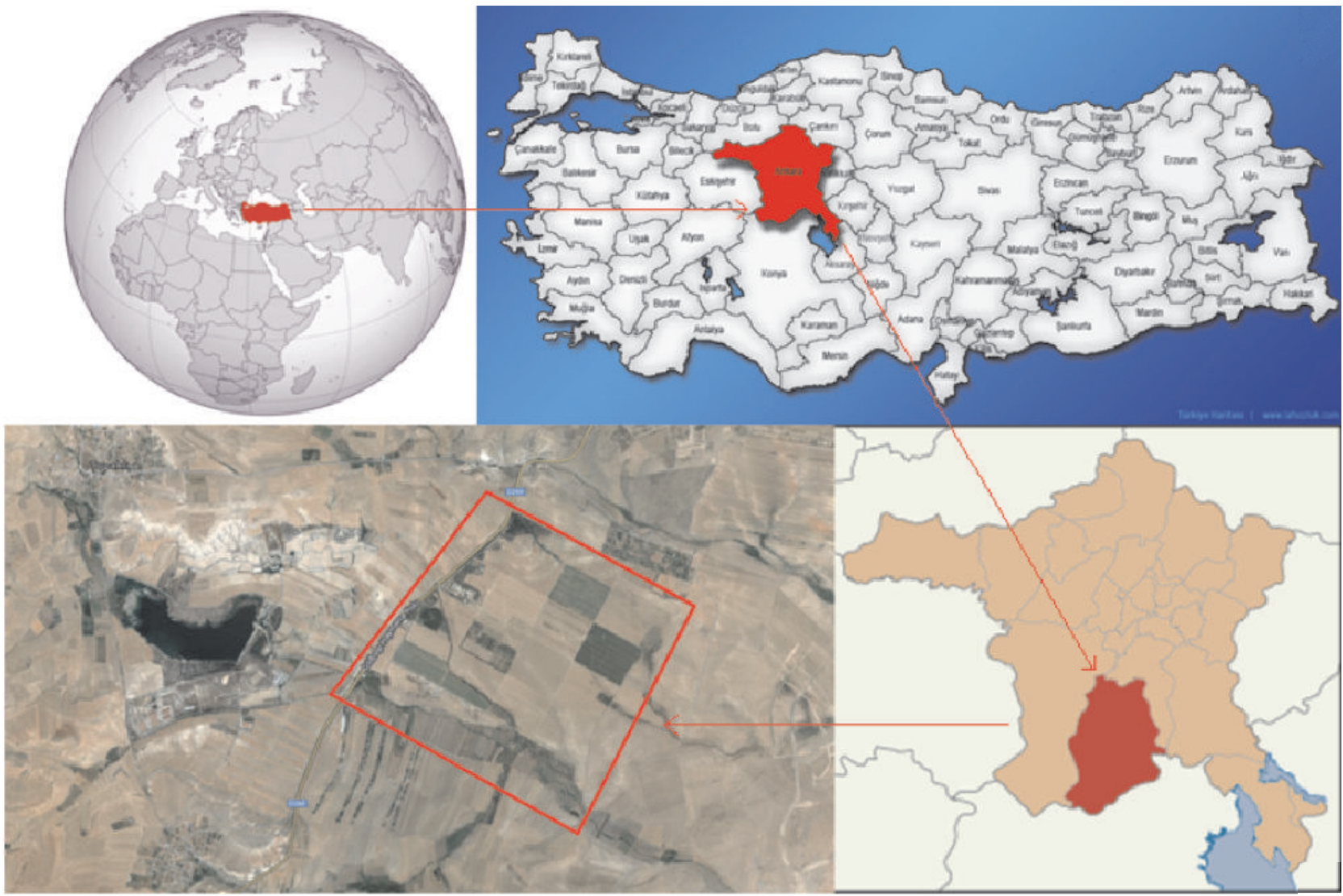

Șekil 1. Araștırma sahası

Figure 1. Research site

\section{Bölgenin İklimi}

Illçede karasal iklimin hüküm sürdüğü görülmektedir. İçe topraklarının 2/3'ünü Haymana Platosu olușturur. En soğuk ay olan Ocak ayında ortalama hava sıcaklığı $-2{ }^{\circ} \mathrm{C}$, en sıcak ay olan Temmuz'da ortalama hava sıcaklığı ise $19^{\circ} \mathrm{C}$ ve yıllık yağıș ortalaması 414 mm'dir (Anonim 2011a, Anonim 2011 b ).

\section{Arazi Kullanım Durumu}

Haymana Araștırma ve Uygulama Çiftliği'nde toprak örneklerinin alındığı yerlerde sertifikalı birinci sınıf ekmeklik buğday tohumluğu, iki sıralı yemlik arpa çeșitleri, silajık mısır üretimi, yonca ve korunga yetiștirilmektedir. Ayrıca elma, erik, kayısı, vișne ve kiraz yetiștiriciliği yapılmaktadır.

\section{Toprak Örneklerinin Alınması ve Yapılan Analizler}

Haymana Araștırma ve Uygulama Çiftliği topraklarında örnek alınacak noktaların belirlenmesi için 250x250 m'lik gridler olușturulmuș ve gridlerin kesișme noktalarından 0-30 cm toprak derinliğinden mikro element bulașmasına yol açmayacak șekilde Jackson (1958) tarafından belirtildiği gibi 65 adet toprak örnekleri alınmıș ve analize hazırlanmıștır.

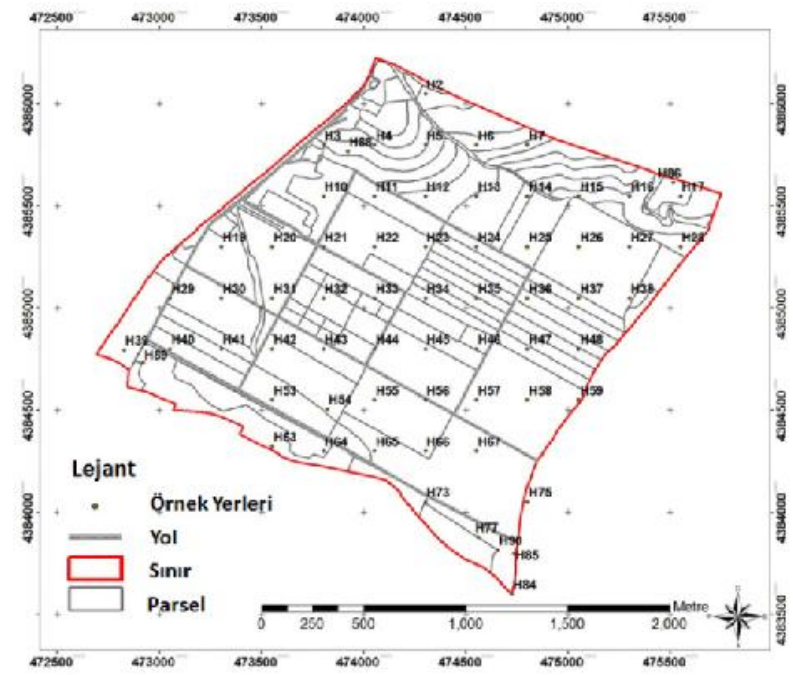

Șekil 2. Çalıșma alanına ait örnekleme yerleri

Figure 2. Research site 
Toprakların fiziksel ve kimyasal özelliklerinden tekstür hidrometre yöntemine göre (Bouyoucos, 1951), toprak reaksiyonu $(\mathrm{pH})$ saturasyon ekstraktında ve elektriksel iletkenlik (EC) saturasyon çamurunda (Richards, 1954), kireç $\left(\mathrm{CaCO}_{3}\right)$ Hızalan ve Ünal (1966), organik madde Jackson (1958) tarafından bildirildiği șekilde modifiye Walkley-Black yaș yakma yöntemine göre, toplam $\mathrm{N}$ Bremner (1965), alınabilir P sodyum bikarbonat $\left(\mathrm{NaHCO}_{3}\right)$ ekstraksiyon (0,5 $\left.\mathrm{M} \mathrm{NaHCO}_{3}, \mathrm{pH}: 8,5\right)$ yöntemiyle (Olsen vd., 1954), alınabilir K nötral amonyum asetat (1 N CH $3 \mathrm{COONH}_{4}, \mathrm{pH}: 7,0$ ) ekstraksiyonunda Jackson (1958), alınabilir Fe, Zn, Cu ve Mn Lindsay ve Norvel (1978) tarafından bildirildiği șekilde dietilen triamin penta asetik asit ekstraksiyonu (DTPA) $\left[0,005 \mathrm{M}\right.$ DTPA + 0,01 M kalsiyum klorür $\left(\mathrm{CaCl}_{2}\right)+$ $0,1 \mathrm{M}$ tri etanol amin (TEA), $\mathrm{pH}$ 7.3)], alınabilir çözünebilir B Wolf (1971) yöntemlerine göre belirlenmiștir. Çalıșma alanı topraklarında yapılan analiz sonuçlarına ilișkin bulgular çizelge l'den yararlanılarak değerlendirilmiștir Elde edilen verilerde korelasyon analizleri SPSS bilgisayar paket programı kullanılarak yapılmıștır (Çizelge 2).

\section{ARAȘTIRMA BULGULARI VE TARTIȘMA}

\section{Toprakların Fiziksel ve Kimyasal Özellikleri}

Haymana Araștırma ve Uygulama Çiftliği topraklarının \%10,8'inin kil tın, \%89,2'sinin de kil bünye sınıfında olduğu belirlenmiștir. Çalıșma alanından alınan toprak örneklerinde belirlenen kil, silt ve kum miktarlarına bağı olarak hazırlanan dağlım haritaları Șekil 3'de verilmiștir. En yüksek kil içeriği \%58, 9 iken, en düșük kil içeriği ise \%32,8 olarak belirlenmiștir. Çiftlik topraklarının \%6,3'ünde \%55-60 (248,2 da), \%53,3'ünde \%50-55 (2107,8

Çizelge 1. Toprakların bazı fiziksel ve kimyasal özellikleri ile besin elementi içeriklerini yorumlamaya ilișkin sınır değerleri

Table 1. The limit rates for interpretation of the nutrient contents with the some physical and chemical properties of soils

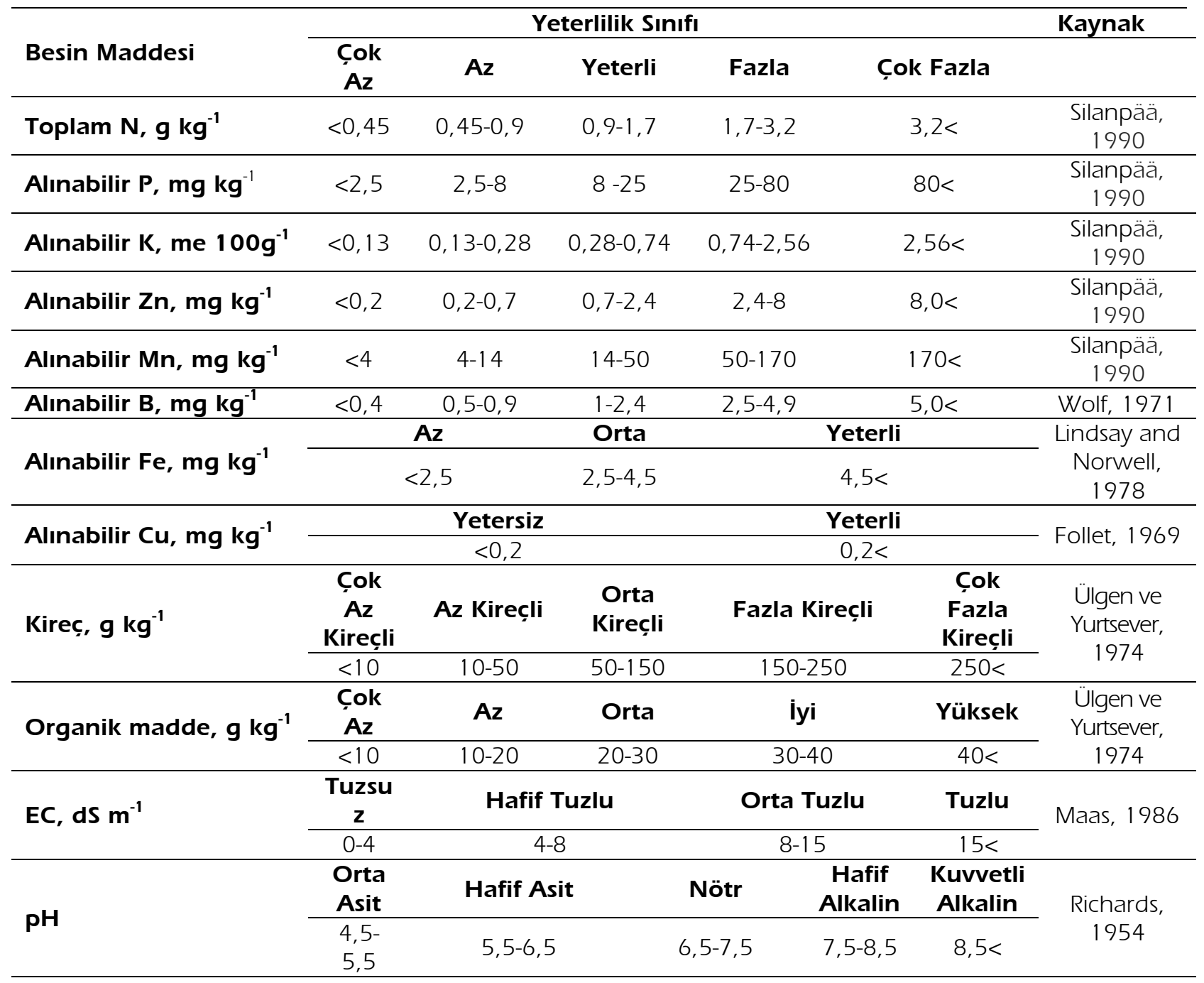


da), \%27,2'sinde \%45-50 (1076,8 da), \%10,3'ünde \%40-45 (409 da), \%2,7'sinde \%35-40 (106,5 da) ve \%0,2'sinde \%30-35 (7,5 da) arasında kil içeriği bulunmuștur. En yüksek silt içeriği \%27,4 iken, en düșük silt içeriğinin ise \%15,1 olduğu belirlenmiștir. Çiftlik topraklarının \%42,2'sinde \%20-30 (1667,4 da) ve \%57,9'inde \%10-20 (2288,4 da) arasında silt içeriği bulunmuștur. En yüksek kum içeriği \%42,5 iken, en düșük kum içeriğinin ise \%21,5 olduğu belirlenmiștir. Çiftlik topraklarının \%0,8'inde \%40-45 (31,8 da), \%6,2'sinde \%35-40 (243,8 da), $\% 31,5^{\prime}$ inde \%30-35 (1246,3 da) ve \%61,5'ünde \%20-30 (2433,9 da) arasında kum içeriği bulunmuștur. Yapılan korelasyon analizi sonucunda; kil ile alınabilir Fe (r: 0,344**) ve silt ile kum (r: $0,408 * * *$ | arasında pozitif bir ilișki bulunurken, kil ile silt ( $\left.r:-0,737^{* * *}\right)$, kil ile kum $\left(r:-0,914^{* * *}\right)$ ve kum ile alınabilir Fe $\left(r\right.$ : $\left.-0,321^{* *}\right)$ arasında negatif bir ilișki tespit edilmiștir (Çizelge 2). Demir, topraktaki birçok kil mineralinin yapı tașıdır (Oades, 1963). Araștırma ve Uygulama Çiftliği topraklarının alınabilir Fe miktarı yetersiz olmasına rağmen kil miktarındaki artıșa bağlı olarak Fe miktarı artmıștır. Benzer ilișkiler Taban vd. (1997), Eyüpoğlu (1999) ve Tümsavaș (2003) tarafından da belirlenmiștir. Killi topraklar verimlilik açısından önem arz ederken, havalanma ve infiltrasyon kapasiteleri sorunludur. Ayrıca killi toprakların su tutma kapasiteleri yüksek olduğundan așırı sulama ya da yağıș durumunda arazide çalıșmak zorlașmaktadır. Ağır bünyeli topraklarda havalanmayı artırmak amacıyla organik gübreler kullanılmasında yarar vardır.

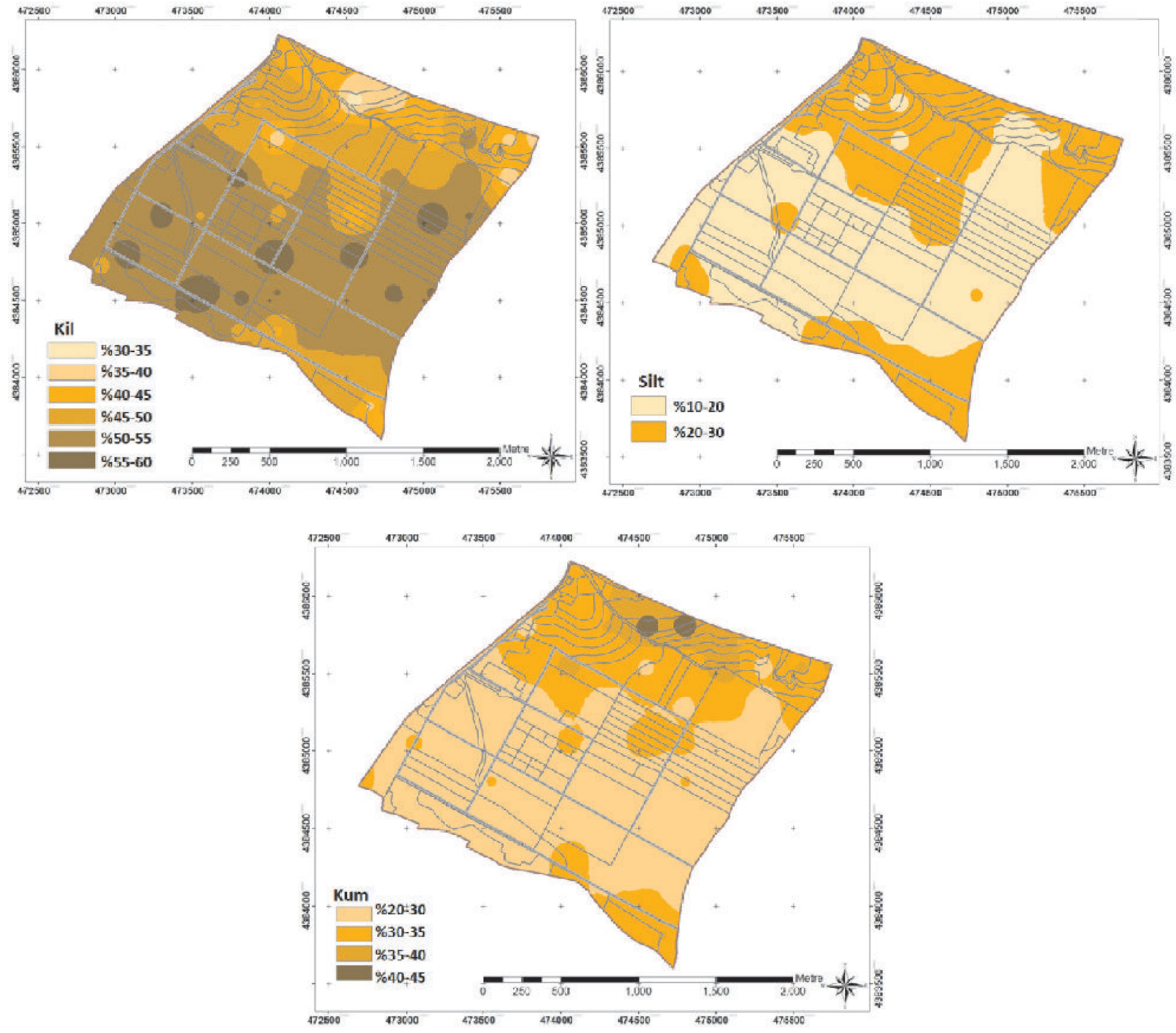

Şekil 3. Çalıșma alanı topraklarının kil, silt ve kum dağıım haritası

Figure 3. The distribution map of clay, silt and sand in soil of the study site 
Çalıșma alanından alınan toprak örneklerinden elde edilen saturasyon ekstraktında belirlenen $\mathrm{pH}$ değerlerine bağlı olarak hazırlanan dağılım haritası Șekil 4'de verilmiștir. En yüksek pH değeri 8,68 iken, en düșük $\mathrm{pH}$ değerinin ise 7,90 olduğu belirlenmiștir. Çiftlik topraklarının \%10,8'inde 8,58,7 (425,5 da) ve \%89,2'sinde 7,5-8,5 (3530 da) arasında $\mathrm{pH}$ değeri bulunmuștur. Yapılan korelasyon analizi sonucunda $\mathrm{pH}$ ile EC (r: $0.389^{* *}$ | arasında pozitif bir ilișki tespit edilmiștir (Çizelge 2). Farklı yöre topraklarında çalıșan bazı araștırıcılarda benzer ilișkileri bulduklarını bildirmișlerdir (Taban vd., 1997; Bozkurt vd., 2000; Bașar 2001; Taban vd., 2004; Bașaran ve Okant, 2005; Alagöz vd., 2006; Tümsavaș ve Aksoy, 2008; Parlak vd., 2008; Bellitürk vd., 2009 ve Turan vd., 2010). Toprak pH'sı, bitkilerin gelișimi ve bitki besin elementlerinin alınabilirliğini önemli derecede etkilemektedir. Çiftlik topraklarında yüksek $\mathrm{pH}$ değerlerini asit karakterli (amonyum sülfat, kükürt vb.) gübrelerin uzun süreli kullanılması ile düșürmek mümkündür (Güçdemir 2006).

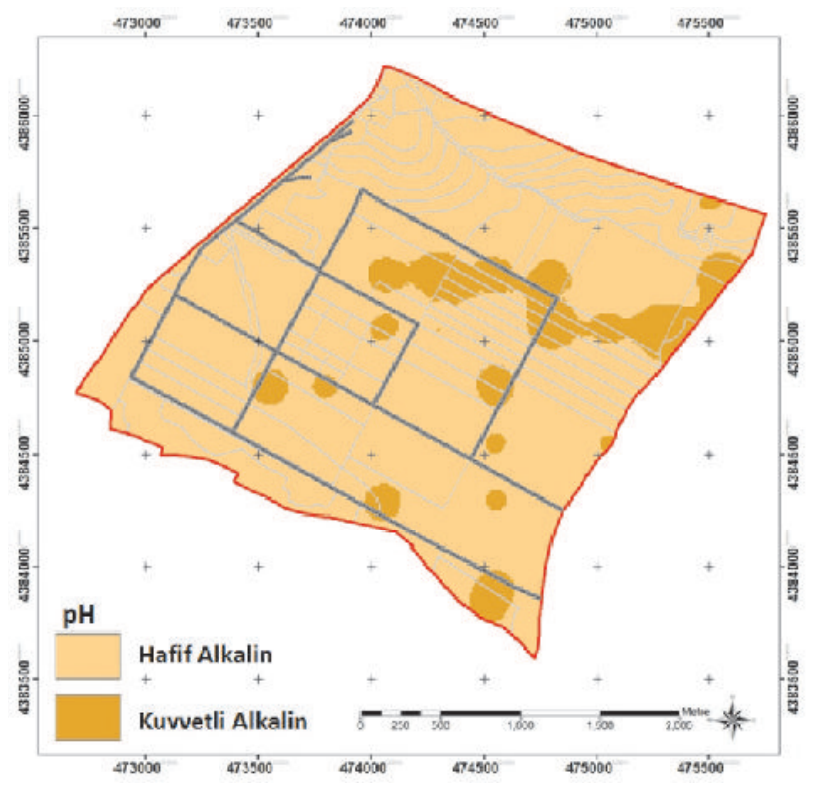

Sekil 4. Çalıșma alanı toprakıarının saturasyon ekstraktından elde edilen $\mathrm{pH}$ dağı̆ım haritası

Figure 4. The distribution map of $\mathrm{pH}$ based on saturation extractin soil of the study site

Çalıșma alanı topraklarının tuz (EC) içerikleri incelendiğinde; en yüksek EC değeri 1,70 dS m iken, en düșük EC değeri ise 0,27 dS m-1 olarak bulunmuștur. Yapılan korelasyon analizi sonucunda; EC ile alınabilir K (r: 0,387**), EC ile alınabilir çözünebilir B (r: $\left.0,820^{* * *}\right)$, EC ile alınabilir Fe (r: $\left.0,619^{* * *}\right)$, EC ile alınabilir Zn (r: 0,435***), EC ile alınabilir Cu (r: 0,312*) ve EC ile alınabilir Mn (r: 0,528***) arasında pozitif bir ilișki tespit edilmiștir (Çizelge 2). Bulunan değerler, topraklarda tarımsal üretimde tuzluluk yönünden herhangi bir sorunun bulunmadığını göstermektedir (Turan vd., 2010).

Calıșma alanından alınan toprak örneklerinde belirlenen kireç ve organik madde (OM) kapsamına bağlı olarak hazırlanan dağılım haritası Șekil 5'de gösterilmiștir. En yüksek kireç içeriği 388,2 $\mathrm{g} \mathrm{kg}^{-1}$ iken, en düșük kireç içeriğinin ise $164,7 \mathrm{~g} \mathrm{~kg}^{-1}$ olduğu belirlenmiștir. Çiftlik topraklarının \%26'sında kireç içeriği $250 \mathrm{~g} \mathrm{~kg}^{-1}$ 'dan fazla $(1026,9$ da) ve \%74'ünde $150-250 \mathrm{~g} \mathrm{~kg}^{-1}(2928,9$ da) arasında bulunmuștur. Bununla birlikte, en yüksek organik madde değeri 21,4 $\mathrm{g} \mathrm{kg}^{-1}$ iken, en düșük organik madde değeri ise $3,8 \mathrm{~g} \mathrm{~kg}^{-1}$ olarak belirlenmiștir. Çiftlik topraklarının \%0, 1 'inde $20-30 \mathrm{~g} \mathrm{~kg}^{-1}$ (5,7 da), \%88, 1 'inde $10-20 \mathrm{~g} \mathrm{~kg}^{-1}$ (3484,2 da) ve $\% 11$, 8'inde $0-10 \mathrm{~g} \mathrm{~kg}^{-1}$ (465,6 da) düzeyinde organik madde belirlenmiștir. Yapılan korelasyon analizi sonucunda OM ile EC $(r$ : 0,294*), OM ile alınabilir çözünebilir B (r: 0,259*), OM ile alınabilir $\mathrm{Fe}\left(r\right.$ : $\left.0,288^{*}\right)$ ve $\mathrm{OM}$ ile alınabilir Zn (r: 0,314*) arasında pozitif ilișki bulunmuș, bunun yanı sıra kireç ile alınabilir Zn (r: -0,259*) ve kireç ile alınabilir $\mathrm{Cu}(\mathrm{r}$ : $-0,250 *)$ arasında ise negatif ilișki tespit edilmiștir (Çizelge 2). Toprakların kireç içeriklerinin yüksek olması bașta $\mathrm{P}$ ve $\mathrm{Zn}$ olmak üzere mikro elementlerin alınımını da güçleștirmektedir (Kacar vd., 1998). Organik madde topraklardaki birçok makro ve mikro bitki besin elementlerinin doğrudan kaynağıdır ve organik maddenin mineralizasyonu sonucu makro ve mikro besin elementleri de toprağa karıșmaktadır (Karaman vd., 2012). Benzer çalıșmalar kireçte Taban vd. (2004), Alagöz vd. (2006), organik maddede Bozkurt vd. (2000), Tümsavaș (2003), Bașaran ve Okant (2005), Parlak vd. (2008), Bellitürk vd. (2009) tarafından da bildirilmiștir. Organik madde bakımından yetersiz olan alanlara 2-3 ton $\mathrm{da}^{-1}$ düzeyinde iyi kompostlanmıș çiftlik gübresi uygulanmasının yararlı olacağı Rosen vd. (1999) tarafından önerilmektedir. 

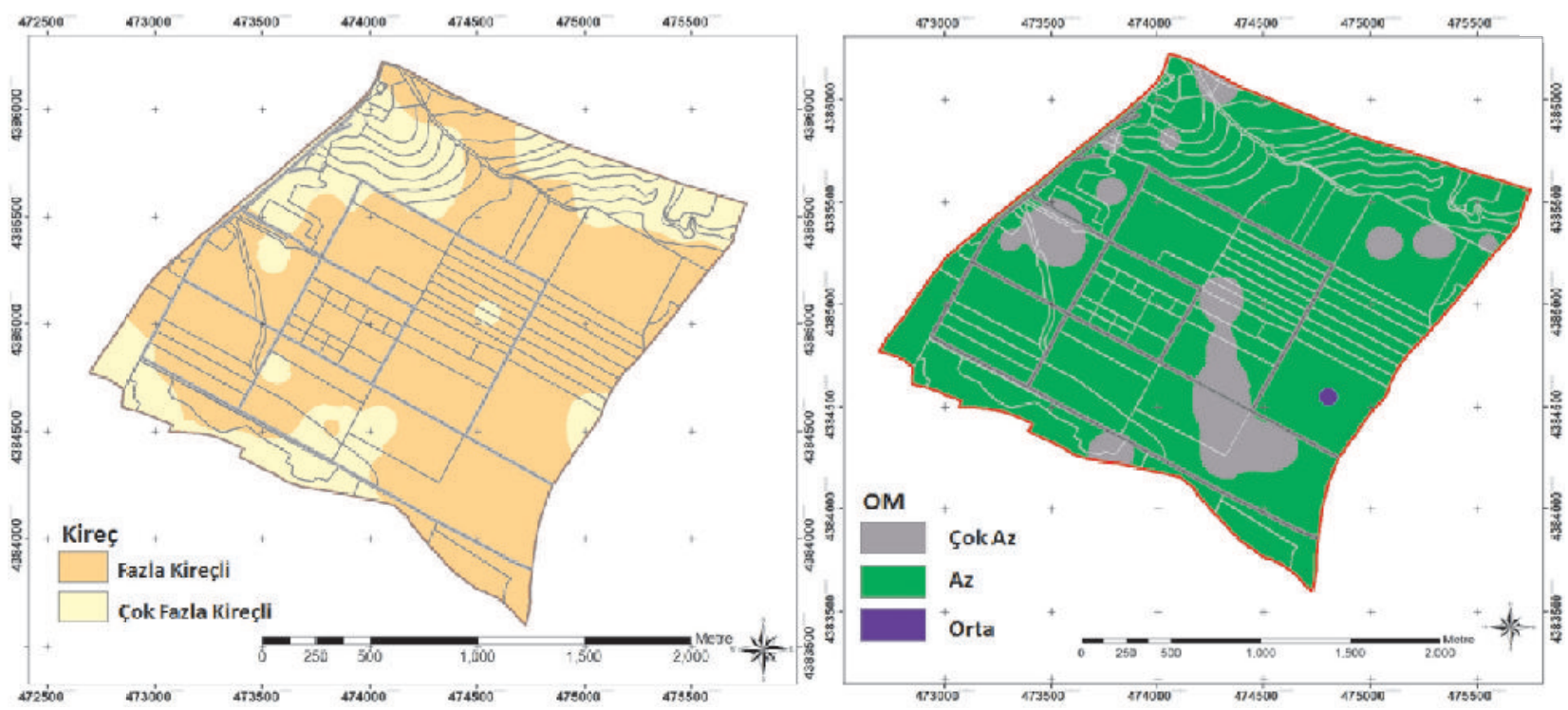

Șekil 5. Çalıșma alanı topraklarının kireç ve organik madde dağıım haritası

Figure 5. The distribution map of lime and organic material in soil the study site

\section{Toprakların Besin Elementi İçerikleri}

Çalıșma alanından alınan toprak örneklerinde belirlenen toplam $\mathrm{N}$, alınabilir $\mathrm{P}$ ve alınabilir $\mathrm{K}$ içeriklerine bağlı olarak hazırlanan dağıım haritası Șekil 6'de verilmiștir. En yüksek toplam N içeriği 6,2 $\mathrm{g} \mathrm{kg}^{-1}$ iken, en düșük toplam $\mathrm{N}$ içeriği $0,8 \mathrm{~g} \mathrm{~kg}^{-1}$ olarak belirlenmiștir. Çiftlik topraklarının \% 1 'inde $3,2 \mathrm{~g} \mathrm{~kg}^{-1}$ dan fazla $(40,2 \mathrm{da}), \% 12,8^{\prime}$ inde 1,7-3,2 $\mathrm{g} \mathrm{kg}^{-1}(504,5 \mathrm{da}), \% 85,9$ 'unda $0,9-1,7 \mathrm{~g} \mathrm{~kg}^{-1}$ (3396,5 da) ve \%0,4'ünde 0,5-0,9 $\mathrm{g} \mathrm{kg}^{-1}$ ( $\left.14,6 \mathrm{da}\right)$ arasında toplam $\mathrm{N}$ bulunmuștur.

En yüksek alınabilir P içeriği $32,4 \mathrm{mg} \mathrm{kg}^{-1}$ iken, en düșük alınabilir $P$ içeriği ise $1,1 \mathrm{mg} \mathrm{kg}^{-1}$ olarak belirlenmiștir. Çiftlik topraklarının \%0,3'ünde 25$80 \mathrm{mg} \mathrm{kg}^{-1}(10,5 \mathrm{da}), \% 40,8^{\prime}$ inde $8-25 \mathrm{mg} \mathrm{kg}^{-1}$ (1614,9 da), \%58,6'sında 2,5-8 mg kg-1 $(2319,5$ da), \%0,3'ünde $0-2,5 \mathrm{mg} \mathrm{kg}^{-1}$ (10,9 da) arasında alınabilir P bulunmuștur.

En yüksek alınabilir K içeriği 2,95 meq $100 \mathrm{~g}^{-1}$ iken, en düșük alınabilir K içeriği 0,28 meq $100 \mathrm{~g}^{-1}$ olarak belirlenmiștir. Çiftlik topraklarının \%0,3'ünde $2,56 \mathrm{meq} 100 \mathrm{~g}^{-1}$ 'dan fazla $(12,1 \mathrm{da}), \% 31,5^{\prime}$ inde 0,74-2,56 meq $100 \mathrm{~g}^{-1}$ (1245,7 da), \%68,2'sinde 0,28-0,74 meq $100 \mathrm{~g}^{-1}$ (2698 da) arasında alınabilir $\mathrm{K}$ bulunmuștur. Yapılan korelasyon analizi sonucunda; alınabilir $P$ ile alınabilir K (r: 0,364**), alınabilir $P$ ile alınabilir Zn (r: 0,496***), alınabilir $P$ ile alınabilir $\mathrm{Cu}\left(r: 0,537^{* * *}\right)$, alınabilir $\mathrm{K}$ ile alınabilir çözünebilir B (r: 0,262*), alınabilir K ile alınabilir Zn (r: 0,473***), alınabilir K ile alınabilir $\mathrm{Cu}\left(\mathrm{r}\right.$ : $\left.0,308^{*}\right)$ ve alınabilir K ile alınabilir $\mathrm{Mn}(\mathrm{r}$ : $0,443^{* *}$ ) arasında pozitif bir ilișki tespit edilmiștir. Toplam azot içeriği Çimrin ve Boysan (2006), Tümsavaș ve Aksoy (2008) tarafından, alınabilir fosfor içeriği Taban vd. (1997), Taban vd. (2004), Parlak vd. (2008) tarafından, alınabilir potasyum ise Taban vd. (1997), Tümsavaș (2003), Taban vd. (2004), Çimrin ve Boysan (2006), Tümsavaș ve Aksoy (2008), Parlak vd. (2008), Turan vd. (2010) tarafından yapılan çalıșmalarla benzerlik göstermektedir. Elde edilen sonuçlara göre çalıșma alanında iyi bir bitki gelișimi için toprak analizlerine bağlı kalarak dengeli bir gübreleme yapılmasının hem toprakların verimliliğini artırabileceği, hem de besin maddelerinden kaynaklanan antagonistik etkileri önleyebileceği düșünülmektedir. 

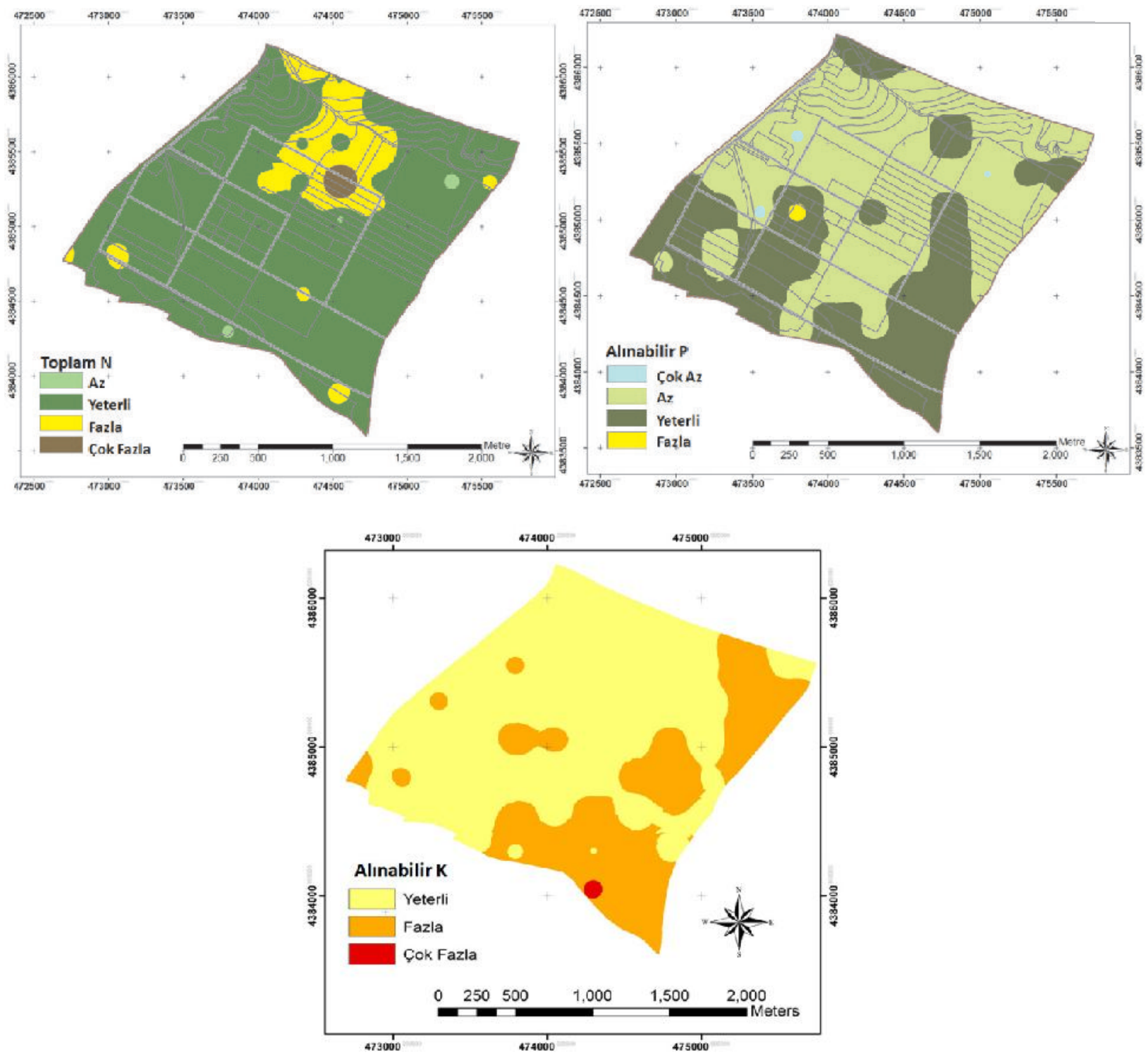

Șekil 6. Çalıșma alanı topraklarının toplam N, alınabilir P ve alınabilir K dağııım haritası

Figure $\mathbf{6}$. The distribution map of total $N$, extractable $P$ and $K$ in soil of the study site

Çalıșma alanından alınan toprak örneklerinde belirlenen alınabilir $\mathrm{Zn}, \mathrm{Mn}$ ve B içeriklerine bağlı olarak hazırlanan dağlım haritası Șekil 7'de verilmiștir. En yüksek alınabilir Zn içeriği 2,9 $\mathrm{mg} \mathrm{kg}^{-1}$ iken, en düșük alınabilir Zn içeriği ise $0,3 \mathrm{mg} \mathrm{kg}^{-1}$ olarak belirlenmiștir. Çiftlik topraklarının \%0,5'inde 2,4-8,0 $\mathrm{mg} \mathrm{kg}^{-1}$ (21,0 da), \%83'ünde $0,7-2,4 \mathrm{mg} \mathrm{kg}^{-1}$ (3282,7 da), \% 16,5'inde 0,2-0,7 $\mathrm{mg} \mathrm{kg}^{-1}$ (652,1 da) arasında alınabilir Zn bulunmuștur.

En yüksek alınabilir $\mathrm{Mn}$ içeriği 4,7 $\mathrm{mg} \mathrm{kg}^{-1}$ iken, en düșük alınabilir Mn içeriği ise $0,7 \mathrm{mg} \mathrm{kg}^{-1}$ olarak belirlenmiștir. Ciftlik topraklarının \%99,6'sında 4-14 $\mathrm{mg} \mathrm{kg}^{-1}$ (3938,5 da) ve \%0,4'ünde 0-4 mg kg-1 (17,3 da) arasında alınabilir Mn bulunmuștur. En yüksek alınabilir çözünebilir B içeriği $5,7 \mathrm{mg} \mathrm{kg}^{-1}$ iken en düșük alınabilir çözünebilir B içeriği ise $0,3 \mathrm{mg} \mathrm{kg}^{-1}$ olarak belirlenmiștir. Ciftlik topraklarının \%0, 1 'inde $5,0 \mathrm{mg} \mathrm{kg}-1$ 'den fazla (3,2 da), \%0,8'inde 2,5-5,0 $\mathrm{mg} \mathrm{kg}^{-1}$ (31,6 da), \%3,2'inde 1-2,5 mg kg-1 (127 da), \%27, 9'unda $0,5-1,0 \mathrm{mg} \mathrm{kg}^{-1}$ (1103,6 da) ve \%68'inde $0,5 \mathrm{mg} \mathrm{kg}^{-1}$ ' den az $(2690,1 \mathrm{da})$ arasında alınabilir çözünebilir B bulunmuștur. Yapılan korelasyon analizi sonucunda; alınabilir $\mathrm{Zn}$ ile alınabilir $\mathrm{Cu}$ (r: 0.520***), alınabilir Zn ile alınabilir Mn (r: $\left.0.410^{* * *}\right)$, alınabilir B ile alınabilir Fe (r: $\left.0.667^{* * *}\right)$, alınabilir B ile alınabilir Zn (r: 0,498***), alınabilir B ile alınabilir Cu (r: $0.423^{* * *}$ ) ve alınabilir B ile alınabilir Mn (r: 0.356***) arasında pozitif ilișki bulunmuștur. Benzer ilișkiler alınabilir Zn içeriği için Taban vd. (1997), Tümsavaș (2003), Tarakçıoğlu vd. (2003), Bașaran ve Okant (2005), Çimrin ve Boysan (2006), Turan vd. (2010), alınabilir Mn içeriği için 
Taban vd. (1997), Bozkurt vd. (2000), Turan vd. (2010) ve alınabilir B içeriği için ise Tarakçıoğlu vd. (2003) tarafından yapılan çalıșmalarda bulunmuștur. Elde edilen sonuçlara göre, çiftlik topraklarına uygun form, doz ve zamanda $\mathrm{Mn}$ ve $\mathrm{B}$ içeren gübrelerin uygulanması gerekmektedir.

Çalıșma alanı topraklarının alınabilir $\mathrm{Fe}$ ve $\mathrm{Cu}$ içerikleri incelendiğinde; en yüksek alınabilir Fe içeriği 2,4 $\mathrm{mg} \mathrm{kg}^{-1}$ iken, en düșük alınabilir Fe içeriği ise 0,6 mg kg-1 olarak belirlenmiștir. Çiftlik topraklarının tamamında 2,5 mg kg-1'den daha az miktarda alınabilir Fe olduğu belirlenmiștir. En yüksek alınabilir $\mathrm{Cu}$ içeriği 3,3 mg kg-1 iken, en düșük alınabilir Cu içeriği ise $0,2 \mathrm{mg} \mathrm{kg}^{-1}$ olarak belirlenmiștir. Çiftlik topraklarının tamamında $0,2 \mathrm{mg} \mathrm{kg}^{-1}$ 'den daha fazla miktarda alınabilir Cu olduğu saptanmıștır. Yapılan korelasyon analizi sonucunda alınabilir Fe ile alınabilir Zn (r: 0,536**), alınabilir Fe ile alınabilir Cu (r:
$0,400^{* * *}$ ) ve alınabilir Fe ile alınabilir $\mathrm{Mn}$ (r: $0,666^{* * *}$ arasında pozitif bir ilișki tespit edilmiștir. Literatürler incelendiğinde alınabilir Fe içeriği için Bașaran ve Okant (2005) tarafından yapılan çalıșma ile alınabilir Cu içeriği için Taban vd. (1997), Bozkurt vd. (2000), Tümsavaș (2003), Tarakçıŏglu vd. (2003), Taban vd. (2004), Bașaran ve Okant (2005), Alagöz vd. (2006), Çimrin ve Boysan (2006), Parlak vd. (2008), Tümsavaș ve Aksoy (2008) ve Turan vd. (2010) tarafından yapılan çalıșmalar ile benzerlik gösterdiği belirlenmiștir. Bitkilerde Fe noksanlığının giderilmesinde demirli gübrelerin bitkilere püskürtülerek uygulanması en ucuz ve en etkin ișlemdir (Pestana vd. 2001, Godsey vd. 2003). Püskürtülerek uygulamanın en önemli yararı kireçli alkalin topraklarda görülen fiksasyon tepkimelerinin olușamamasıdır. Çoğu bitkilere demir sülfatın \%z'lik çözeltileri, demir noksanlığının giderilmesinde bașarılı șekilde püskürtülerek uygulanabilir (Kacar 2013).

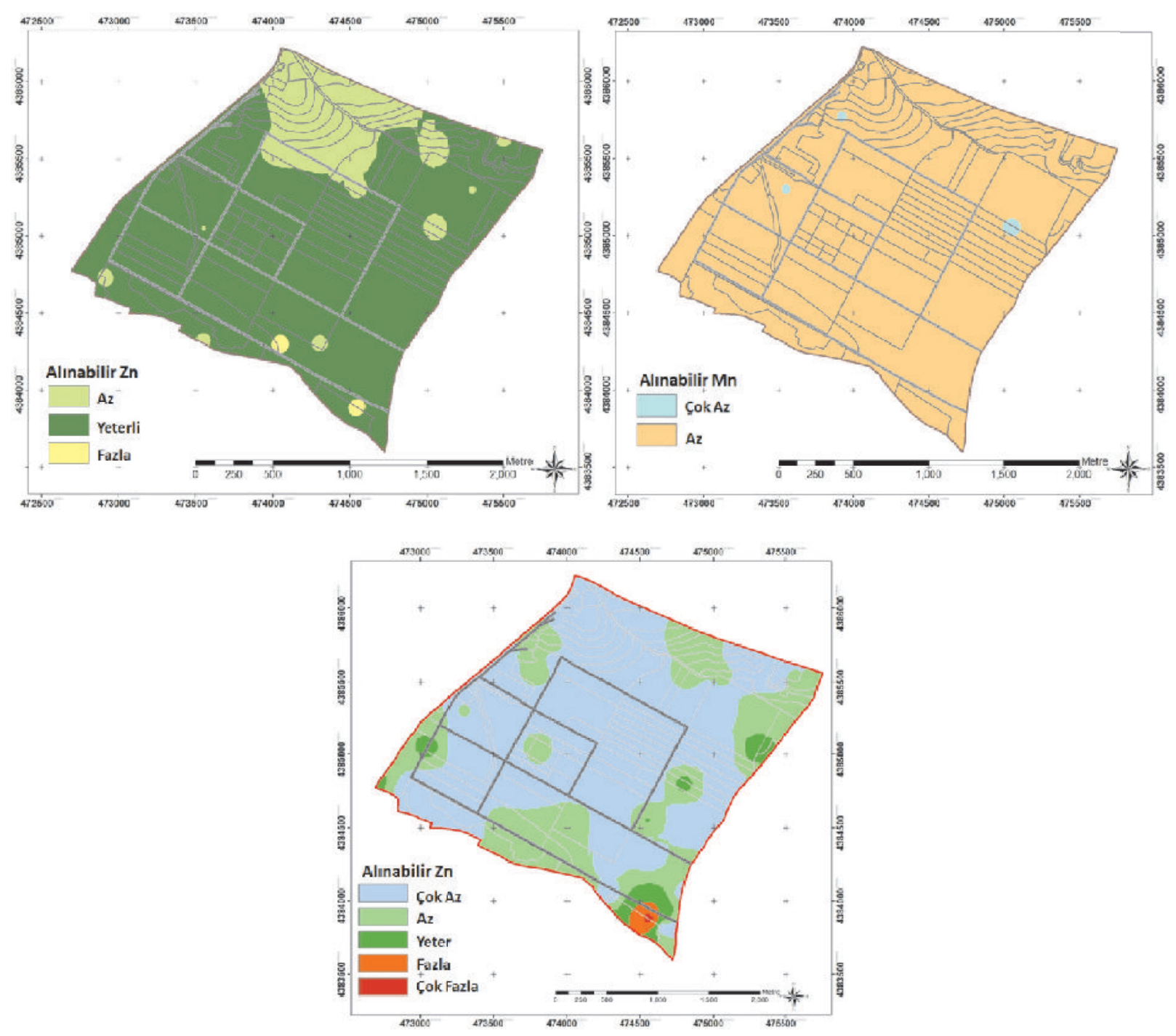

Șekil 7. Çalıșma alanı topraklarının alınabilir Zn ve Mn ve B dağlım haritası

Figure 7. Distribution map of extractable $\mathrm{Zn}$ and $\mathrm{Mn}$, and $\mathrm{B}$ in soil of the study site 
Çizelge 2. Haymana Araștırma ve Uygulama Çiftliği Topraklarının Bazı Fiziksel ve Kimyasal Özellikleri Arasındaki Korelasyon Katsayıları

Table 2. The Correlation Factors Between Some Physical and Chemical Properties of Haymana Research and Application Farm Soils

\begin{tabular}{|c|c|c|c|c|c|c|c|c|c|c|c|c|c|c|}
\hline & Kil & Silt & Kum & OM & $\mathrm{pH}$ & EC & Kireç & $\mathbf{N}$ & $\mathbf{P}$ & $\mathbf{K}$ & B & $\mathrm{Fe}$ & $\mathrm{Zn}$ & $\mathrm{Cu}$ \\
\hline Silt & $-0.737^{* \star *}$ & & & & & & & & & & & & & \\
\hline Kum & $-0.914^{* * *}$ & $0.408^{* * *}$ & & & & & & & & & & & & \\
\hline OM & -0.038 & 0.132 & -0.008 & & & & & & & & & & & \\
\hline $\mathrm{pH}$ & -0.119 & 0.174 & 0.035 & 0.104 & & & & & & & & & & \\
\hline EC & -0.102 & 0.184 & 0.026 & $0.294^{*}$ & $0.389^{* *}$ & & & & & & & & & \\
\hline Kireç & -0.166 & 0.114 & 0.144 & -0.227 & -0.157 & -0.092 & & & & & & & & \\
\hline $\mathbf{N}$ & -0.050 & -0.001 & 0.080 & 0.210 & 0.179 & 0.040 & -0.230 & & & & & & & \\
\hline $\mathbf{P}$ & -0.001 & -0.074 & 0.058 & 0.166 & -0.137 & 0.056 & -0.223 & 0.002 & & & & & & \\
\hline K & -0.089 & 0.179 & 0.017 & 0.022 & 0.088 & $0.387^{* *}$ & -0.241 & 0.051 & $0.364^{* *}$ & & & & & \\
\hline B & -0.048 & 0.038 & 0.044 & $0.259^{*}$ & 0.110 & $0.820^{* * *}$ & -0.003 & 0.006 & 0.165 & $0.262^{*}$ & & & & \\
\hline $\mathrm{Fe}$ & $0.344^{* *}$ & -0.221 & $\overline{-} 0.321^{* *}$ & $0.288^{*}$ & 0.073 & $0.619^{* * *}$ & -0.151 & -0.041 & 0.147 & 0.225 & $0.667^{* * *}$ & & & \\
\hline Zn & 0.094 & -0.099 & -0.078 & $0.314^{*}$ & 0.201 & $0.435^{* * *}$ & $-0.259^{*}$ & -0.030 & $0.496^{* * *}$ & 0.473 & $0.498^{* * *}$ & $0.536^{* * *}$ & & \\
\hline $\mathrm{Cu}$ & 0.200 & -0.155 & -0.170 & 0.138 & -0.012 & $0.312^{*}$ & $-0.250^{*}$ & -0.031 & $0.537^{* * *}$ & $0.308^{*}$ & $0.423^{* * *}$ & $0.400^{* * *}$ & $0.520^{* * *}$ & \\
\hline Mn & 0.027 & 0.057 & -0.051 & 0.213 & 0.006 & $0.528^{* * *}$ & -0.206 & -0.048 & 0.230 & $0.443^{* * *}$ & $0.356^{* * *}$ & $0.666^{* * *}$ & $0.410^{* * * *}$ & 0.199 \\
\hline
\end{tabular}

\section{SONUC}

Haymana Araștırma ve Uygulama Çiftliği topraklarının fiziksel analiz sonuçlarına göre toprakların büyük kısmının ağır bünyeli, hafif alkali, tuzsuz, kireçli ve düșük organik maddeye sahip olduğu belirlenmiștir. Bitki besin maddesi analiz sonuçlarına göre toprakların toplam $\mathrm{N}$, alınabilir $\mathrm{K}$ ve alınabilir Zn ve Cu bakımından yeterli olduğu, diğer taraftan alınabilir P, Fe ve Mn ile alınabilir çözünebilir B bakımından yetersiz olduğu bu çalıșma ile belirlenmiștir. Analiz sonuçlarına göre, çiftlik topraklarında besin maddesi noksanlıklarını gidermede mikro element içeren gübrelerle fizyolojik asit karakterli gübreler tercih edilmelidir. Toprakların organik madde kapsamı ile havalanma kapasitesinin artması amacıyla da dekara 3-4 ton ahır gübresi uygulanması faydalı olacaktır.

\section{KAYNAKLAR}

Alagöz Z, Öktüren F, Yılmaz E (2006). Antalya bölgesinde karanfil yetiștirilen sera topraklarının bazı verimlilik özelliklerinin belirlenmesi. Akdeniz Üniversitesi Ziraat Fakültesi Dergisi, 19(1): 123-129.

Anonim (2011a). Available: http://tr.wikipedia.org/wiki/Ha ymana. (Erișim tarihi: 25.10.2011)
Anonim (2011b). Available:http://www.haymana.gov.tr/ default_B1.aspx?content=186. (Erișim tarihi: 22.10.2011)

Anonim 2015a. http://mmw.lafsozluk.com/2011/01/dunyaharitasi-uzerinde-Turkiye-yeri-konumu.html. (Erișim tarihi: 28.01.20151

Anonim2015b. http://mww.lafsozluk.com/2012/01/ankarailinin-turkiye-haritasindaki-yeri.html. (Erișim tarihi: 28.01.2015)

Bașar H (2001). Bursa ili topraklarının verimlilik durumlarının toprak analizleri ile incelenmesi. Uludağ Üniversitesi Ziraat Fakültesi Dergisi, 15(2): 69-83.

Bașaran M, Okant, M (2005). Bazı toprak özelliklerinin Eldivan yöresinde yetiștirilen kirazların beslenme durumu üzerine etkisi. Tarım Bilimleri Dergisi, 11 (2): 115-1 19.

Bellitürk K, Danıșman F, Sözübek B (2009). Tekirdağ yöresindeki toprakların bazı fiziksel ve kimyasal özellikleri ile mineralizasyon kapasiteleri arasındaki ilișkiler. Akdeniz Üniversitesi Ziraat Fakültesi Dergisi, 22(2): 141-147.

Bouyoucos G J (1951). A recalibration of hydrometer method for making mechanical analysis of soils. Agronomy Journal, 43: 434-438.

Bozkurt M A, Çimrin K M, Karaca S (2000). Aynı koșullarda yetiștirilen üç farklı elma çeșidinde beslenme durumlarının değerlendirilmesi. Ankara Üniversitesi Ziraat Fakültesi Tarım Bilimleri Dergisi, 6(4): 101-105. 
Bremner J M (1965). Total nitrogen. In: Methods of soil analysis Part 2. Chemical and microbiological properties. Black, C.A. (ed.), Amer. Soc. Of Agron. Inc. Pub. Agron. Series. No: 9. pp. 1149-1178, Madison, Wisconsin, USA

Çimrin K M, Boysan S (2006). Van yöresi tarım topraklarının besin elementi durumları ve bunların bazı toprak özellikleriyle ilișkileri. Yüzüncü Yıl Üniversitesi Ziraat Fakültesi Tarım Bilimleri Dergisi, 16: 105-111.

Eyüpoğlu F (1999). Türkiye topraklarının verimlilik durumu. Toprak ve Gübre Araștırma Enstitüsü Yayınları, Ankara.

Follet R H (1969). Zn, Fe, Mn and Cu in Colorado Soils. Ph. D. Dissertation. Colorado State University.

Godsey C B, Schmidt J P, Schlegel A J, Taylor R K, Thompson C R, Gehl R J (2003). Correcting iron deficiency in corn with seed row applied iron sulfate. Agron. J., 95, 160 166.

Güçdemir i (2006). Türkiye Gübre ve Gübreleme Rehberi Genel Yayın No: 231. Teknik Yayın No: T.69. Ankara.

Hızalan E, Ünal H (1966). Topraklarda önemli kimyasal analizler. Ankara Üniversitesi Ziraat Fakültesi Yayınları, Ankara.

Jackson M L (1958). Soil chemical analysis. pp. 1-498. Prentice Hall, Inc. Englewood Cliffs, New Jersey, USA.

Kacar B, Taban S, Alpaslan M, Fuleky G (1998). Zinc phosphorus relationship in the dry matter yield and the uptake of $\mathrm{Zn}, \mathrm{P}, \mathrm{Fe}$ and $\mathrm{Mn}$ of rice plants (Oryza sativa L.) as affected by the total carbonate content of the soil. Second International Zinc Symposium. Abstracts, pp. 20, 2-3 October, Ankara, Turkey.

Kacar B (2013). Temel Gübre Bilgisi. Nobel Yayın, 502 Ankara.

Karaman M R, Brohi A R, Müftüoğlu N M, Öztaș T, Zengin M (2012). Sürdürülebilir toprak verimliliği, Koyulhisar Ziraat Odası Kültür Yayınları, Tokat.

Lindsay W L, Norvell W A (1978). Development of a DTPA soil test for zinc, iron, manganese and copper. Soil Science Society of American Proceeding 42: 421-428

Maas E V (1986). Salt Tolerance of Plants. Applied Agricultural Research, 1: 12-26.

Oades J M (1963). The nature and distribution of iron compounds in soil. Soil and Fertilizers, 26, 69-80.

Olsen S R, Sommers L E (1982). Phosphorus, In: Page L A Miller R H. Keeney D R, ed. Methods of soil analysis, Part 2. Chemical and microbiological properties, pp.539-579, Madison, Wisconsin, American Society of Agronomy.

Parlak M, Fidan A, Kızılcık I, Koparan H (2008). Eceabat ilçes tarım topraklarının verimlilik durumlarının belirlenmesi. Ankara Üniversitesi Ziraat Fakültesi Tarım Bilimleri Dergisi, 14(4): 394-400.
Pestana M, Correia P J, Varennes A, Abadia J, Faria E A (2001). Effectiveness of different foliar Fe applications to control Fe chlorosis in orange trees grown on a calcareous soil. J. Plant Nutr., 24, 613-622

Richards L A (1954). Diagnosis and Improvement of Saline and Alkali Soils. United States Department of Agriculture Handbook, 60

Rosen C, Becker R, Fritz V, Huthicson B, Percich J, Tong C, Wrigth J (1999). Growing Garlic in Minnesota. Available: http://www.Extension.umn.edu/distribution/ cropsystems/components/7.317-mulching.html. (Erișim tarihi: 24.06.2014)

Silanpää M (1990). Micronutrient assessment at country level: An international study. In: FAO Soils Bulletin. N.63. Rome.

Taban S, Alpaslan M, Hasemi A G, Eken D (1997). Orta Anadolu'da çeltik tarımı yapılan toprakların bazı fiziksel ve kimyasal özellikleri. Pamukkale Üniversitesi Mühendistik Fakültesi Mühendislik Bilimleri Dergisi. 3(3): 457-466.

Taban S, Cııklı Y, Cebeci F, Taban N, Sezer S M (2004). Tașköprü yöresinde sarımsak tarımı yapılan toprakların verimlilik durumu ve potansiyel beslenme problemlerinin ortaya konulması. Tarım Bilimleri Dergisi, 10(3): 297-304.

Tarakçıŏlu C, Yalçın S R, Bayrak A, Küçük M, Karabacak H (2003). Ordu yöresinde yetiștirilen fındık bitkisinin beslenme durumunun toprak ve yaprak analizleriyle belirlenmesi. Tarım Bilimleri Dergisi, 9(1): 13- 22

Turan M A, Katkat A V, Özsoy G, Taban S (2010). Bursa ili alüviyal tarım topraklarının verimlilik durumları ve potansiyel beslenme sorunlarının belirlenmesi. Uludağ Üniversitesi Ziraat Fakültesi Dergisi, 24(1): 115-130.

Tümsavaș Z (2003). Bursa ili Vertisol büyük toprak grubu topraklarının verimlilik durumlarının toprak analizleriyle belirlenmesi. Uludağ Üniversitesi Ziraat Fakültesi Dergisi, 17(2): 9-21.

Tümsavaș Z, Aksoy E (2008). Kahverengi Orman büyük toprak grubu topraklarının verimlilik durumlarının belirlenmesi. Uludağ Üniversitesi Ziraat Fakültesi Dergisi, 22(1): 43-54.

Ülgen N, Yurtsever N (1995). Türkiye Gübre ve Gübreleme Rehberi. Toprak ve Gübre Araștırma Enstitüsü Yayınları, Genel Yayın No: 209, Teknik Yayınlar No: T.66, Ankara.

Ülgen N, Yurtsever N (1974). Türkiye Gübreler ve Gübreleme Rehberi. Toprak ve Gübre Araștırma Enstitüsü Müdürlüğü, Teknik Yayınlar No:28. Ankara.

Wolf B (1971). The determination of boron in soil extracts, plant materials, composts, manures, water and nutrient solutions. Soil Science and Plant Anal., 2(5): 363-374. 